\title{
Pre-service primary school mathematics teachers' beliefs on mathematics assessment
}

\author{
Kimura Patar Tamba ${ }^{1}$, Wiputra Cendana ${ }^{1 *}$, Adegoke Adegbite ${ }^{2}$ \\ ${ }^{1}$ Universitas Pelita Harapan. Jl. M. H. Thamrin Boulevard 1100 Lippo Village Tangerang 15811 - Indonesia \\ ${ }^{2}$ Texas A\&M University. 400 Bizzell St, College Station, TX 77843, United States \\ * Corresponding Author. E-mail: wiputra.cendana@gmail.com
}

Received: 21 December 2020; Revised: 14 January 2021; Accepted: 18 March 2021

\begin{abstract}
Assessment is an important component in learning mathematics. The practice of mathematics assessment is influenced by teachers' beliefs about the assessment. This study aims to explore the beliefs of primary school mathematics teachers regarding mathematics assessment. The research used quantitative research methods using survey methods to 71 prospective elementary school mathematics teachers. Confidence data regarding mathematics assessment was collected using closed and open questionnaires based on a framework of productive beliefs and unproductive beliefs. Data from closed questionnaires were analyzed using descriptive statistics. Meanwhile, open questionnaire data were analyzed using deductive coding method based on productive and unproductive beliefs. The results showed that prospective elementary school mathematics teachers held mixed beliefs in mathematics assessment. On the one hand, it can be said that the beliefs of prospective elementary school mathematics teachers regarding mathematics assessment tend to be contradictory. These results imply the importance of an attempt to intervene in the beliefs of prospective elementary school mathematics teachers regarding mathematics assessment. Thus, assessment practice can lead to productive assessment, which is to encourage meaningful mathematics learning.
\end{abstract}

Keywords: assessment, mathematics, belief, practice

How to Cite: Tamba, K., Cendana, W., \& Adegbite, A. (2021). Pre-service primary school mathematics teachers' beliefs on mathematics assessment. Jurnal Prima Edukasia, 9(2), 158167. doi:https://doi.org/10.21831/jpe.v9i2.36815

\section{Introduction}

Assessment is an important component in mathematics education. All learning processes always involve assessment components and activities. An excellent mathematics program ensures that assessment is an integral part of teaching (National Council of Teachers of Mathematics, 2014). NCTM defines assessment as a process of gathering evidence showing students' knowledge of mathematics, their ability to use mathematics, and their disposition concerning mathematics, and then drawing a conclusion from the data, which are then used for various suitable purposes (National Council of Teachers of Mathematics, 2014). Assessment can also be defined as the process of analyzing the students' progress: whether they have learned everything that was expected (Baird et al., 2017). Zhao et al. (2016) defined assessment as a process where the students' responses to stimuli (both stimuli that are specifically made for a certain purpose, or that occur spontaneously), are collected to draw conclusions about the students' knowledge and skills. In other words, there are at least two important elements in assessment: gathering evidence and making decisions based on that evidence.

The aim of assessments is to support the learning process. One that affects the quality of learning is the quality of the assessment carried out (Brown, 2006). However, in reality, assessment often becomes an obstacle towards the development of students' mathematical abilities. This is because traditionally, assessment is considered to be a process that emphasizes the evaluation of student achievement (eg. grading). It is even used to determine school rankings and teacher performance (National Council of Teachers of Mathematics, 2014). This is contradictory to the fact that the current assessment reformation focuses on the continuous providing of knowledge and information to support the students' and teachers' learning and teaching process. This view differs from the fundamental view of assessment, where assessment is seen as a series of objective processes that together should be a tool for measuring students' knowledge. 
Jurnal Prima Edukasia, 9 (2), 2021 - 159

Kimura Patar Tamba, Wiputra Cendana, Adegoke Adegbite

This traditional view of assessment propelled a number of researchers and mathematics education community members to call for assessment reform in mathematics education (Barnes et al., 2014; Herwin et al., 2019; Lui \& Bonner, 2016). A teacher's pedagogic abilities will be determined by by their beliefs in teaching, learning, and assessment (Doğan, 2011), and this the reason why assessment reform is crucial. A teacher's belief in mathematics assessments and assessing will affect their assessment process in the classroom (Martínez-Sierra et al., 2020; Suurtamm et al., 2016; Syafitri, 2020). Furthermore, He et al. (2011) revealed that the success of the education policy regarding assessments at the practical level will be determined by the teachers' beliefs in assessment.

On the other hand, research on teachers' confidence in assessment is still very limited (MartínezSierra et al., 2020; Suurtamm et al., 2016). However, there seems to be an increasing interest regarding this topic. This can be seen through the development of assessment instruments that is continuously being carried out and tested in various contexts. Brown (2006) developed the Teachers ' Conceptions of Assessment (TCoA). Brown used four components of belief (conceptions): first, assessment can contribute to the improvement of teaching and learning processes (Improvement); second, assessments can be used to evaluate the effectiveness of schools and teachers (School Accountability); third, assessments can validate student performance, holding them accountable for results (Student Accountability); fourth, assessments may be deemed fundamentally irrelevant to the professional and personal lives of teachers and students (Not relevant). TCoA has been widely used as a research instrument in various countries, conducted in various languages, and diverse contexts. TCoA has also been used to compare conceptions of cross-cultural assessment (Brown \& Remesal, 2012; Brown \& Wang, 2016), conceptions in relation to policy (Brown et al., 2015), and used in various countries such as China (Brown \& Gao, 2015), Taiwan (Chen et al., 2012) and Canada (Daniels et al., 2014). Apart from TCoA, the Student 'Conceptions of Assessment (SCoA) was also developed (Brown, 2011; Brown \& Hirschfeld, 2007). In addition to the TCoA and SCoA instruments, another instrument that has been developed is the Qualitative Model of Conceptions of Assessment (QMCoA) (Remesal, 2011). The QMCoA was developed based on four aspects that will influence the teaching and learning process, namely (1) the act of teaching, (2) the act of learning, (3) the act of providing accreditation or certificates for certain learning outcomes, and (4) the act of giving accountability to agents outside of the classroom, including school administrators, families, and policy makers.

None of the various previous studies explained above has used the productive and non-productive frameworks when analyzing teachers' confidence in assessments. NCTM (2014) classifies teachers' beliefs in assessment into productive beliefs and unproductive beliefs. This categorization is based on the role of the assessment in the teaching and learning process. Productive belief means that the teacher sees assessment as a tool that can be used to support and emphasize effective teaching and learning. On the other hand, unproductive beliefs mean that the teacher sees assessment merely as something that measures the students' achievement, limiting students to only the core math content and practices (National Council of Teachers of Mathematics, 2014). An example of productive belief is the confidence that students are able to assess their own learning process. Unproductive belief, however, believes that assessments must be carried out by agents other than the student and not the students themselves. It is important to understand productive and unproductive frameworks in understanding belief in assessment because the assessment reform that is currently being pushed by researchers and mathematics education community members is actively moving towards the productive assessment framework. In addition, no previous research has analyzed the assessment beliefs of pre-service elementary school mathematics teachers. This topic is worthy of inquiry because one of the keys to carry out assessment reform is based on the confidence of pre-service teachers (National Council of Teachers of Mathematics, 2014).

This research aims to explore the assessment beliefs of pre-service elementary school mathematics teachers. Specifically, this study will explore the productive and unproductive beliefs regarding assessment held possessed by pre-service elementary school mathematics teachers. This research aims to answer this question: What is the belief regarding assessment held by pre-service elementary school mathematics teachers?

\section{Method}

This research uses the quantitative research method, conducted using the survey method. This method was chosen because it is suitable for a research that aims to describe a situation that existed in the past or in the present (Cohen et al., 2002). 
Jurnal Prima Edukasia, 9 (2), 2021 - 160

Kimura Patar Tamba, Wiputra Cendana, Adegoke Adegbite

\section{Participants}

The participants in this study are 71 pre-service elementary school teachers (10 male and 61 female). All participants have completed all courses on general pedagogy, mathematics content courses (basic mathematics, geometry, elementary school mathematics) and are currently taking courses on mathematics teaching. The participants were divided into two groups: those with classes conducted in Indonesian, and those with classes conducted in two languages (Indonesian and English).

Instrument

The data collected in this study is data on the pre-service elementary school mathematics teachers' belief in mathematics assessment. The data were collected through a questionnaire. The questionnaire consists of two parts: the open-ended question section and the close-ended question section. The closeended question section consists of questions adapted from the productive belief of mathematics assessment and the unproductive belief of mathematics assessment from National Council of Teachers of Mathematics (2014). The items in the section are then divided into two groups: the productive belief dimension (eg. "The main objective of assessment is to become proof of students' accountability shown through daily test scores or report card scores") and the unproductive belief dimension (eg. "in learning mathematics, students are capable of assessing their own work"). There are a total of 12 items, six of which are questions in the productive belief dimension and the other six are on the unproductive belief dimension. This questionnaire uses a six-point Likert scale $(1=$ "strongly disagree" to $5=$ "strongly agree").

The open-ended question section presents three questions: (i) what do you think an assessment is, and what is its purpose? (ii) what type of assessment is suitable for the purpose of learning mathematics? (iii) what will you do with the assessment results acquired? These three questions are presented to analyze the beliefs regarding the essence, purpose and form of mathematics assessment held by preservice elementary school mathematics teachers. Data collection was done through Microsoft form.

Analysis

There are several stages of data analysis carried out in this research. The first stage is to analyze the questionnaire construction. The questionnaire was composed based on the theoretical framework of NCTM (2014), which divides mathematical assessment beliefs into productive beliefs and unproductive beliefs. Because the basis of this questionnaire are two components that have had an existing factor structure, the testing of the instrument's construction was done using the confirmatory factor analysis (Brown et al., 2015). Confirmatory factor analysis (CFA) examines the suitability of a series of pathways of and between factors by making use of the factor patterns, covariance patterns, and residual or error values in the data matrix. After the CFA, validation tests were carried out, using the correlation of product moment and reliability measured using Cronbach's Alpha.

The data analysis of the close-ended questions is carried out using the quantitative descriptive method: calculating the mean and standard deviation for each of the confidence dimensions ("productive" and "unproductive"). The dimension that has a higher mean value is the belief dimension that pre-service elementary school teachers tend to hold. The analysis is performed using the AMOS software and SPSS 20.0.

Data from the open-ended question questionnaires are analyzed using the deductive coding method (Cohen et al., 2002). The coding used follows two dimensions of mathematical assessment beliefs: the productive and unproductive beliefs. The results from the open-ended question analysis will be compared with the results from the closed-question analysis.

\section{Results and Discussion}

The results of this study are presented in two parts. The first part describes the construction of the instrument used to analyze beliefs regarding mathematical assessment. The second part describes the belief held by pre-service elementary school mathematics teachers regarding mathematics assessments.

Confirmatory factor analysis

In this study, the value of Kaiser-Meyer-Olkin Measure of Sampling Adequacy is 0.57 and the value of Bartlett's Test of Sphericity is $228.45(\mathrm{p}=0.00<0.05)$. This means that the prerequisite for 
Jurnal Prima Edukasia, 9 (2), 2021 - 161

Kimura Patar Tamba, Wiputra Cendana, Adegoke Adegbite

analysis confirmatory factor (Confirmatory factor analysis/CFA) has been met. Adhering to the CFA analysis results, four of the 12 items were removed. One statement (statement 11, regarding self-assessment) was removed because its loading factor does not meet the requirements of $>0.3$ (Brown et al., 2015). Statements 8 and 12 were removed because there was a component overlap (the questions contain more than one component/factor). Statement 6 was also removed because it was found to be inconsistent with theoretical construct: the statement was put in the productive belief dimension, while theoretically, the statement belongs to the opposite dimension. The updated questionnaire, then, consisted of eight items. CFA analysis was carried out once again for the new questionnaire with eight items. Table 1 shows the result of the final CFA analysis.

Table 1. Factor loadings of two factors based on CFA

\begin{tabular}{|c|c|c|}
\hline Item & Loading & Mean \\
\hline \multicolumn{3}{|l|}{ I. Unproductive Belief } \\
\hline $\begin{array}{l}\text { P1. The main objective of assessment is to become proof of students' accountability } \\
\text { shown through daily test scores or report card scores }\end{array}$ & 0.69 & 4.27 \\
\hline $\begin{array}{l}\text { P2. There must be a certain time allocated for assessing so as not to interfere with the } \\
\text { rest of the learning process }\end{array}$ & 0.76 & 4.03 \\
\hline $\begin{array}{l}\text { P3. The most suitable assessment for mathematics education is essay questions and } \\
\text { multiple-choice questions because they are reliable and objective }\end{array}$ & 0.71 & 4.44 \\
\hline $\begin{array}{l}\text { P4. One form of assessment (either essay or multiple choice) can be used to conclude a } \\
\text { student's understanding of mathematics }\end{array}$ & 0.62 & 4.20 \\
\hline P5. Assessment is designed for the students & 0.62 & 3.80 \\
\hline \multicolumn{3}{|l|}{ II. Productive Belief } \\
\hline $\begin{array}{l}\text { P7. The main purpose of assessment is to inform and improve the mathematics } \\
\text { learning process }\end{array}$ & 0.72 & 5.14 \\
\hline $\begin{array}{l}\text { P9. The understanding of mathematics and its processes can be measured through } \\
\text { various strategies and task-based assessments }\end{array}$ & 0.82 & 5.11 \\
\hline $\begin{array}{l}\text { P 10. Multiple data sources are needed to provide an accurate representation of teacher } \\
\text { and student performance }\end{array}$ & 0.83 & 5.24 \\
\hline
\end{tabular}

This mathematics assessment belief measurement model with two factors has been tested with the CFA, showing adequate results $\left(\mathrm{k}=8 ; \chi^{\wedge} 2=16,94 ; \mathrm{df}=19 ; \mathrm{p}=0.594 \mathrm{CFI}=1.00\right.$; RMSEA $=0.00$; AGFI $=0.899$; GFI $=0.946$ ). The questionnaire instrument consists of eight items. These eight items are divided into two factors (components): the productive belief section with three items and the unproductive belief section with five items. After the CFA, a validity analysis was performed using the Pearson correlation and reliability with Cronbach's Alpa. The Pearson correlation value for each statement item ranges from 0.236 to 0.695 and is significant for $\alpha=0,05$. This Pearson correlation value indicates that the questionnaire is valid. This questionnaire also has high reliability. This is shown through the Cronbach's Alpha value of 0.612, which is higher than 0.5.

Description of Mathematical Assessment Beliefs

The descriptive analysis results of the closed-ended question questionnaire are shown in Table 2. The average score of unproductive beliefs is 4.15 . This means that pre-service elementary school mathematics teachers hold unproductive beliefs when it comes to mathematics assessments. The score on productive belief is 5.16. This also shows that pre-service elementary school mathematics teachers hold productive beliefs regarding mathematics assessments. The average score for productive beliefs is higher than the average score for non-productive beliefs. This means that pre-service elementary school mathematics teachers are more likely to hold productive beliefs regarding mathematics assessments. In other words, pre-service elementary school teachers hold productive beliefs regarding mathematics assessments at a rate that is higher than their conviction of unproductive belief.

Table 2. Pre-service elementary school mathematics teachers' belief on mathematics assessment based on the close-ended question questionnaire

\begin{tabular}{lcccc}
\hline & Min. & Max. & Mean & Std.Dev \\
\hline Unproductive Belief & 1.40 & 5.60 & 4.15 & 0.79 \\
Productive Belief & 3.00 & 6.00 & 5.16 & 0.53 \\
\hline
\end{tabular}


Jurnal Prima Edukasia, 9 (2), 2021 - 162

Kimura Patar Tamba, Wiputra Cendana, Adegoke Adegbite

However, the fact that the mean score of unproductive belief is higher than 4 indicates that preservice elementary school mathematics teachers also have a high rate of unproductive belief. This means that even though they incline towards the productive belief, the pre-service teachers hold both productive and unproductive beliefs.

Based on Table 1, the mean value on P1, 4.57, is lower than the mean value of P7, 5.14. This indicates that pre-service elementary school mathematics teachers tend to have more productive belief than unproductive beliefs. In terms of the types and strategies of mathematics assessment, pre-service elementary school mathematics teachers also tend to hold productive beliefs. This is seen through the mean value for P9 (productive belief) that is higher than the mean value for P3 and P4 (unproductive belief). Likewise, in terms of the usage of assessment results, pre-service elementary school mathematics teachers tend to have productive beliefs. This can be seen through the mean value of P10 (productive belief) which is higher than the mean value of P5 (unproductive belief).

Table 2 shows the open-question questionnaire analysis results. There are three open-ended questions in the questionnaire: What do you think an assessment is, and what is its purpose? (Q1), What type of assessment is suitable for the purpose of learning mathematics? (Q2), and What will you do with the assessment results acquired? (Q3). The analysis results of the open-ended questions show a negative correlation to the results of the closed-ended question questionnaire above. In Table 2, it is seen that based on the question of an assesment's purpose (Q1), the frequency of pre-service elementary school mathematics teachers having unproductive belief is 60 . This is higher than the frequency of productive belief regarding an assessment's purpose of 11 . This means that pre-service elementary school mathematics teachers tend to have unproductive belief regarding the purpose or nature of assessments. Likewise, in terms of assessment types and strategies, pre-service elementary school mathematics teachers tend to hold unproductive belief. The frequency of Q1 is higher for unproductive belief than for productive belief. Meanwhile, in regard to the usage of assessment results, pre-service elementary school mathematics teachers tend to have unproductive belief. The frequency of Q3 statements is higher for unproductive belief (47) than for productive belief (24).

The analysis results of the open-ended questionnaire show that pre-service elementary school mathematics teachers tend to have unproductive beliefs regarding mathematics assessment. This finding is negatively correlated with the results acquired from the closed-ended questionnaire.

Table 2. Belief in Mathematics Assessment based on the Open Questionnaire

\begin{tabular}{|c|c|c|c|}
\hline Belief & Question & Sample Response & Freq \\
\hline \multirow[t]{3}{*}{$\begin{array}{l}\text { Unproductive } \\
\text { Belief }\end{array}$} & Q1 & $\begin{array}{l}\text { Assessment is an evaluation on students done through assignments or } \\
\text { exercises which are useful for measuring the extent to which children } \\
\text { understand the material taught. }\end{array}$ & 60 \\
\hline & Q2 & $\begin{array}{l}\text { In my opinion, essay questions are suitable because the teacher can see } \\
\text { the mathematics process done by the students. }\end{array}$ & 51 \\
\hline & Q3 & $\begin{array}{l}\text { It provides opportunities for students to know themselves better and fix } \\
\text { their mistakes. }\end{array}$ & 47 \\
\hline \multirow[t]{3}{*}{$\begin{array}{l}\text { Productive } \\
\text { Belief }\end{array}$} & Q1 & $\begin{array}{l}\text { Assessment is a systematic form of evaluation that is carried out after part } \\
\text { or all the learning materials has been learned. The aim is to evaluate } \\
\text { student development and as evaluation for the teacher themselves in the } \\
\text { teaching process. }\end{array}$ & 11 \\
\hline & Q2 & $\begin{array}{l}\text { There are many assessment forms that can be used in mathematics such } \\
\text { as multiple-choice, matching, short answers, independent practice, } \\
\text { teaching aids and so on, but an assessment in the form of short } \\
\text { descriptions is adequate for knowing the students' ability to answer } \\
\text { questions (and the process of finding said answer). Other types of } \\
\text { assessments that can be related to other subjects, such as art (drawing, } \\
\text { creating songs, etc.) or ICT (presentations with PPT, and others can also } \\
\text { be used. }\end{array}$ & 20 \\
\hline & Q3 & $\begin{array}{l}\text { I will analyze and collect data to re-assess students' abilities and then help } \\
\text { the students to understand parts of the lesson that may not have been } \\
\text { understood well, and then conduct an assessment again. However, I also } \\
\text { need analyze the way I teach and better it. }\end{array}$ & 24 \\
\hline
\end{tabular}


Jurnal Prima Edukasia, 9 (2), 2021 - 163

Kimura Patar Tamba, Wiputra Cendana, Adegoke Adegbite

\section{Discussion}

Based on the results described above, the findings of this research can be grouped into two parts. The first finding is the instrument used to measure belief in mathematic assessments. The use of the categorization system from NCTM (2014) and the validation approach with confirmatory factor analysis (CFA), Pearson's Moment-product statistics and Cronbach's Alpha resulted in 8 items used in the final instrument to measure belief in mathematics assessment. These eight items measure two aspects of mathematical assessment beliefs: the productive belief (three items) and unproductive belief (five items). Productive belief means that the assessment supports effective teaching and learning. Meanwhile, unproductive belief means that the assessment is seen only as a tool for measuring achievement, which limits students to important math content and practices (National Council of Teachers of Mathematics, 2014). This division of beliefs is based on the issue of assessment reform, which is to encourage assessment that supports effective teaching and learning (Baird et al., 2017; Barnes \& Marks, 2013; Dixon \& Haigh, 2009; Suurtamm et al., 2016; Suurtamm \& Koch, 2014; Zhao et al., 2016). This means that this instrument is suitable to be used to analyze the beliefs of pre-service elementary school mathematics teachers in relation to the assessment reform project. This instrument differs from the belief instruments or assessment conception used by previous studies. The TCoA instrument analyzes four aspects of belief: improvement (used to evaluate learning processes), school accountability (used to evaluate schools), student accountability (used to hold students accountable for their actions), and irrelevance (assessments may be deemed fundamentally irrelevant to the professional and personal lives of teachers and students) (Brown, 2006; Brown \& Remesal, 2017). When compared with TCoA and SCoA, this instrument focuses more specifically on the context of mathematics teaching and learning, while TCoA and SCoA has a wider scope, focusing on the assessment system. TCoA, for example, focuses on broader aspects up to the context of school accountability, while the instrument used in this research does not. Meanwhile, when compared to QMCoA, the instrument used here has similarities in terms of focus: the QMCoA also focuses on aspects concerning the teaching and learning process (Remesal, 2011). However, QMCoA specifically tests assessment beliefs based on the view that assessing is an act of giving accreditation or certification of learning outcomes and accountability. This is not the case in this study. In addition, when looking at assessment beliefs, TCoA, SCoA and QMCoA only focuses on the goal, or aim, of the assessments themselves. The instrument used in this research, on the other hand, also considers belief in the use of the assessment results, types, and strategies.

The second finding is the results on the assessment beliefs held by pre-service elementary school mathematics teachers. Based on the close-ended question questionnaire, pre-service elementary school mathematics teachers tend to hold the productive belief in assessment as opposed to the unproductive belief. Meanwhile, the results of the open-ended question questionnaire show the opposite. This means that pre-service elementary school mathematics teachers tend to have mixed beliefs, both the productive and unproductive. This mixed belief may indeed occur, as previously revealed in previous research regarding the beliefs of pre-service teachers and mathematics teachers (Beswick, 2012; Felbrich et al., 2012; Tang \& Hsieh, 2014; Yang et al., 2020). A number of other studies on the topic of the beliefs of pre-service teachers and mathematics teachers have also shown the possibility of a teacher holding mixed or inconsistent beliefs (Op't Eynde et al., 2002; Xenofontos, 2018). Many previous research convinces the existence of the relation between assessment belief and teaching and learning belief. It means this mixed belief affects by their mixed beliefs in mathematics, teaching and learning mathematics. Chen \& Brown research (2016) shows that tension between transmissive learning and the learning which centered to the students to affect the assessment. Nevertheless, furthermore research is needed to strengthen this analysis.

Moreover, the previous research shows the belief of teacher and pre-service teacher affected by Education policy (Brown et al., 2015; Brown \& Remesal, 2012; Gebril \& Brown, 2014). 2013 curriculum supported productive assessment policy, even though not all the policies has been done and implemented well yet, especially in assessment. The evidence can be seen in assessment approaching in text book that school use, because the text book is the practical evidence of policy implementation (Lepik et al., 2015; Pepin et al., 2013; Viholainen et al., 2015). The result of the research about the textbook that being use in 2013 curriculum shows that not all the textbooks are using the productive assessment well yet. For example the implementation of authentic assessment (one of the productive assessment form), the text book did not covers all of the required elements (Adi, 2017; Ferryka, 2017; 
Jurnal Prima Edukasia, 9 (2), 2021 - 164

Kimura Patar Tamba, Wiputra Cendana, Adegoke Adegbite

Maryati et al., 2019). Therefore, practically mathematics assessment still done in mixed way. However, further research is needed to strengthen this analysis.

Based on the results and discussions, this research can contribute to the study of assessment beliefs in two ways. First, this study proposes an instrument to measure mathematic assessment belief that is different from the instruments used in previous studies. This study proposes an instrument that can test beliefs in mathematic assessments based on productive and unproductive aspects. This aspect is very important to measure because it is directly in line with the issue of mathematics assessment reform (Baird et al., 2017; Dixon \& Haigh, 2009; Leslie, 2013; Suurtamm et al., 2016; Suurtamm \& Koch, 2014; Zhao et al., 2016). Second, this study describes and reveals that pre-service elementary school mathematics teachers tend to hold mixed beliefs about mathematics assessment. In addition to the fact that these teachers tend to hold mixed beliefs, these results also indicate an inconsistency in beliefs held by pre-service elementary school mathematics teachers. Further research will be needed to discuss this issue more extensively.

Regardless, this study has its limitations. The above findings should be reviewed while considering the following limitations: the instrument construction approach (questionnaire) has several drawbacks. The statement items have not been elaborated more extensively. These items are directly drawn from the theoretical constructs of National Council of Teachers of Mathematics (2014), which means that this theoretical construct may not be very operational. In addition, the limited number of statement items means that when an item does not pass the statistical test, the aspect that the item was supposed to analyze becomes forgotten and unexamined. For example, P8, a statement regarding the timing of the assessment on the category of productive confidence, does not pass the statistical test. As a result, the categorization of aspects of confidence based on the time of the assessment was not present in the questionnaire. Another limitation is concerning the construction and validation of statement items. This study did not use the EFA (Exploratory Factor Analysis) approach. Although the factor construction has been carried out theoretically, the use of EFA will help in further elaborating possible factor categories that differ from the theoretical framework. In addition, the small amount of sample is also a weakness in this study. The results, findings and limitations of this study have implications for further research. Further research needs to test the instrument constructed and introduced in this study. This is needed so that researchers can have an instrument that is valid and reliable. Also, the reasons behind the mixed or inconsistent beliefs needs to be investigated further.

\section{Conclusion}

First, it is possible to construct an instrument that measures belief regarding mathematical assessments using aspects of productive beliefs and unproductive beliefs. This instrument consists of eight statement items and has good validation based on confirmatory factor analysis (CFA), Pearson's moment-product correlation and Cronbach's Alpha. Second, pre-service elementary school mathematics teachers hold mixed beliefs regarding mathematics assessment. This conclusion is reached due to the results of the open-ended question questionnaire and the close-ended question questionnaire showing different belief tendencies.

The practical implication of these findings is that there needs to be a conscious effort to change the beliefs of pre-service elementary school mathematics teachers regarding mathematics assessments. This is important because various theories and previous studies have shown that the trajectory of educational practice, in this case mathematics assessment, is determined by teacher beliefs.

\section{References}

Adi, Y. K. (2017). A content analysis of thematic-integrative, scientific approach, and authentic assessment in the second grade of elementary school textbook theme 6. Jurnal Prima Edukasia, 5(2), 211-224. https://doi.org/10.21831/jpe.v5i2.9393

Baird, J.-A., Andrich, D., Hopfenbeck, T. N., \& Stobart, G. (2017). Assessment and learning: fields apart? Assessment in Education: Principles, Policy \& Practice, 24(3), 317-350. https://doi.org/10.1080/0969594X.2017.1319337

Barnes, N., Fives, H., \& Dacey, C. M. (2014). Teachers' beliefs about assessment. In H. Fives \& M. G. Gill (Eds.), International Handbook of Research on Teachers'Beliefs (pp. 284-300).

Routledge. https://doi.org/10.4324/9780203108437-25 
Jurnal Prima Edukasia, 9 (2), 2021 - 165

Kimura Patar Tamba, Wiputra Cendana, Adegoke Adegbite

Beswick, K. (2012). Teachers' beliefs about school mathematics and mathematicians' mathematics and their relationship to practice. Educational Studies in Mathematics, 79(1), 127-147. https://doi.org/10.1007/s10649-011-9333-2

Brown, G. T. L. (2006). Teachers' conceptions of assessment: Validation of an abridged version. Psychological Reports, 99(1), 166-170. https://doi.org/10.2466/pr0.99.1.166-170

Brown, G. T. L. (2011). Self-regulation of assessment beliefs and attitudes: A review of the students' conceptions of assessment inventory. Educational Psychology, 31(6), 731-748. https://doi.org/10.1080/01443410.2011.599836

Brown, G. T. L., Chaudhry, H., \& Dhamija, R. (2015). The impact of an assessment policy upon teachers' self-reported assessment beliefs and practices: A quasi-experimental study of Indian teachers in private schools. International Journal of Educational Research, 71, 50-64. https://doi.org/10.1016/j.ijer.2015.03.001

Brown, G. T. L., \& Gao, L. (2015). Chinese teachers' conceptions of assessment for and of learning: Six competing and complementary purposes. Cogent Education, 2(1), 1-19. https://doi.org/10.1080/2331186X.2014.993836

Brown, G. T. L., \& Hirschfeld, G. H. F. (2007). Students' conceptions of assessment and mathematics: Self-regulation raises achievement. Australian Journal of Educational and Developmental Psychology, 7(1), 63-74. https://www.newcastle.edu.au/_data/assets/pdf_file/0017/100358/v7brown-hirschfeld.pdf

Brown, G. T. L., \& Remesal, A. (2012). Prospective teachers' conceptions of assessment: A crosscultural comparison. The Spanish Journal of Psychology, 15(1), 75-89. https://doi.org/10.5209/rev_SJOP.2012.v15.n1.37286

Brown, G. T. L., \& Remesal, A. (2017). Teachers' conceptions of assessment: Comparing two inventories with Ecuadorian teachers. Studies in Educational Evaluation, 55(June), 68-74. https://doi.org/10.1016/j.stueduc.2017.07.003

Brown, G. T. L., \& Wang, Z. (2016). Understanding Chinese university student conceptions of assessment: cultural similarities and jurisdictional differences between Hong Kong and China. Social Psychology of Education, 19(1), 151-173. https://doi.org/10.1007/s11218-015-9322-x

Chen, C.-H., Crockett, M. D., Namikawa, T., Zilimu, J., \& Lee, S. H. (2012). Eighth grade mathematics teachers' formative assessment practices in SES-different classrooms: A Taiwan study. International Journal of Science and Mathematics Education, 10(3), 553-579. https://doi.org/10.1007/s10763-011-9299-7

Cohen, L., Manion, L., \& Morrison, K. R. B. (2002). Research methods in education. Routledge.

Daniels, L. M., Poth, C., Papile, C., \& Hutchison, M. (2014). Validating the conceptions of assessment-III scale in Canadian preservice teachers. Educational Assessment, 19(2), 139-158. https://doi.org/10.1080/10627197.2014.903654

Dixon, H., \& Haigh, M. (2009). Changing mathematics teacher's conceptions of assessment and feedback. Teacher Development, 13(2), 173-186. https://doi.org/10.1080/13664530903044002

Doğan, M. (2011). Student teachers' views about assessment and evaluation methods in mathematics. Educational Research and Reviews, 6(5), 417-431. https://academicjournals.org/article/article1379688817_Dogan.pdf

Felbrich, A., Kaiser, G., \& Schmotz, C. (2012). The cultural dimension of beliefs: an investigation of future primary teachers' epistemological beliefs concerning the nature of mathematics in 15 countries. ZDM - International Journal on Mathematics Education, 44(3), 355-366. https://doi.org/10.1007/s11858-012-0418-x

Ferryka, P. Z. (2017). Analyzing the thematic-integrative content, the scientific approach, and the authentic assessment in the theme 1 textbook for grade II students of elementary schools. Jurnal Prima Edukasia, 5(2), 172. https://doi.org/10.21831/jpe.v5i2.14285

Gebril, A., \& Brown, G. T. L. (2014). The effect of high-stakes examination systems on teacher beliefs: Egyptian teachers' conceptions of assessment. Assessment in Education: Principles, Policy and Practice, 21(1), 16-33. https://doi.org/10.1080/0969594X.2013.831030 
Jurnal Prima Edukasia, 9 (2), 2021 - 166

Kimura Patar Tamba, Wiputra Cendana, Adegoke Adegbite

He, Q., Valcke, M., \& Aelterman, A. (2011). Pre-service teachers' beliefs about evaluation. Procedia Social and Behavioral Sciences, 29, 1296-1304. https://doi.org/10.1016/j.sbspro.2011.11.366

Herwin, H., Tenriawaru, A., \& Fane, A. (2019). Math elementary school exam analysis based on the Rasch model. Jurnal Prima Edukasia, 7(2), 106-113. https://doi.org/10.21831/jpe.v7i2.24450

Lepik, M., Grevholm, B., \& Viholainen, A. (2015). Using textbooks in the mathematics classroom the teachers 'view. Nordic Studies in Mathematics Education, 20((3-4)), 129-156.

Leslie, D. (2013). Debates in mathematics education. In G. Ineson \& H. Povey (Eds.), Debates in Mathematics Education. Routledge. https://doi.org/10.4324/9780203762585

Lui, A. M., \& Bonner, S. M. (2016). Preservice and inservice teachers' knowledge, beliefs, and instructional planning in primary school mathematics. Teaching and Teacher Education, 56(1), 1-13. https://doi.org/10.1016/j.tate.2016.01.015

Martínez-Sierra, G., García-García, J., Valle-Zequeida, M., \& Dolores-Flores, C. (2020). High school mathematics teachers' beliefs about assessment in mathematics and the connections to their mathematical beliefs. International Journal of Science and Mathematics Education, 18(3), 485507. https://doi.org/10.1007/s10763-019-09967-2

Maryati, M., Zubaidah, E., \& Mustadi, A. (2019). A content analysis study of cientific approach and authentic assessment in the textbook of curriculum 2013. Jurnal Prima Edukasia, 7(2), 128138. https://doi.org/10.21831/jpe.v7i2.26792

National Council of Teachers of Mathematics. (2014). Principles to actions: Ensuring mathematical success for all. The National Council of Teachers of Mathematics, Inc.

Op't Eynde, P., De Corte, E., \& Verschaffel, L. (2002). Framing students' mathematics-related beliefs. In G. Leder, E. Pehkonen, \& G. T€orner (Eds.), Beliefs: A Hidden Variable in Mathematics Education? (pp. 13-37). Springer Netherlands. https://doi.org/10.1007/0-306-47958-3_2

Pepin, B., Gueudet, G., \& Trouche, L. (2013). Investigating textbooks as crucial interfaces between culture, policy and teacher curricular practice: Two contrasted case studies in France and Norway. ZDM - International Journal on Mathematics Education, 45(5), 685-698. https://doi.org/10.1007/s11858-013-0526-2

Remesal, A. (2011). Primary and secondary teachers' conceptions of assessment: A qualitative study. Teaching and Teacher Education, 27(2), 472-482. https://doi.org/10.1016/j.tate.2010.09.017

Suurtamm, C., \& Koch, M. J. (2014). Navigating dilemmas in transforming assessment practices: experiences of mathematics teachers in Ontario, Canada. Educational Assessment, Evaluation and Accountability, 26(3), 263-287. https://doi.org/10.1007/s11092-014-9195-0

Suurtamm, C., Thompson, D. R., Kim, R. Y., Moreno, L. D., Sayac, N., Schukajlow, S., Silver, E., Ufer, S., \& Vos, P. (2016). Assessment in Mathematics Education: Large-Scale Assesment and Classroom Assessment. Springer. https://doi.org/10.1007/978-3-319-32394-7

Syafitri, D. (2020). Peningkatan motivasi dan hasil belajar matematika melalui alat peraga pada siswa sekolah dasar. Teacher in Educational Research, 2(2), 63-70. https://doi.org/10.33292/ter.v2i2.77

Tang, S. J., \& Hsieh, F. J. (2014). The cultural notion of teacher education: Future lower secondary teachers' beliefs on the nature of mathematics, the learning of mathematics and mathematics achievement. In S. Blömeke, F. J. Hsieh, G. Kaiser, \& W. Schmidt (Eds.), The Conceptualisation of Mathematics Competencies in the International Teacher Education Study TEDS-M (pp. 231-253). Springer. https://doi.org/10.1007/978-94-007-6437-8_20

Viholainen, A., Partanen, M., Piiroinen, J., Asikainen, M. A., \& Hirvonen, P. E. (2015). The role of textbooks in Finnish upper secondary school mathematics: theory, examples and exercises. Nordic Studies in Mathematics Education, 20(3-4), 154-178.

Xenofontos, C. (2018). Greek-Cypriot elementary teachers ' epistemological beliefs about. Teaching and Teacher Education, 70(1), 47-57. https://doi.org/10.1016/j.tate.2017.11.007

Yang, X., Kaiser, G., König, J., \& Blömeke, S. (2020). Relationship between pre - service mathematics teachers ' knowledge, beliefs and instructional practices in China. ZDM, 52(2), 281-294. https://doi.org/10.1007/s11858-020-01145-x 
Jurnal Prima Edukasia, 9 (2), 2021 - 167

Kimura Patar Tamba, Wiputra Cendana, Adegoke Adegbite

Zhao, X., Van den Heuvel-Panhuizen, M., \& Veldhuis, M. (2016). Teachers' use of classroom assessment techniques in primary mathematics education - an explorative study with six Chinese teachers. International Journal of STEM Education, 3(1).

https://doi.org/10.1186/s40594-016-0051-2 